ISSN: 1410-8917
Jurnal Kimia
Suins \&

\title{
Cytotoxic Activity of Ethyl-para-methoxycinnamate from Kaempferia galanga L. on A549 Lung Cancer and B16 Melanoma Cancer Cells
}

\author{
Riza Apriani a, ${ }^{\text {, }}$, Fajar Fauzi Abdullah ${ }^{\mathrm{a}}$ \\ ${ }^{\text {a }}$ Department of Chemistry, Faculty of Mathematics and Natural Science, Universitas Garut, Garut, Indonesia \\ *Corresponding author: aprianiriza@uniga.ac.id \\ https://doi.org/10.14710/jksa.24.1.22-28
}

\section{Article Info}

Article history:

Received: 6 $6^{\text {th }}$ December 2020 Revised: $27^{\text {th }}$ February 2021 Accepted: $28^{\text {th }}$ February 2021 Online: $28^{\text {th }}$ February 2021

Keywords:

A549 cell; B16 cell; cytotoxic; Ethyl-p-methoxycinnamate (EPMC), Kaempferia galanga $\mathrm{L}$

\begin{abstract}
Kaempferia galanga L. belongs to the family of Zingiberaceae, an endangered medicinal plant with pharmacology activities. Ethyl-p-methoxycinnamate (EPMC) is an essential phytoconstituent of $K$. galanga rhizomes. Several studies have reported that EPMC has anticancer activities in several cancer cells, including CL- 6 gallbladder cancer cells, HepG2 liver cancer cells, MCF-7 breast cancer cells, and Raji lymphoma cancer cells. However, studies on A549 lung cancer and B16 melanoma cancer cells have not been reported. This study aimed to determine the anticancer activity of EPMC against A549 lung cancer and B16 melanoma cancer cells. EPMC was obtained by extraction using $n$-hexane, then recrystallized with chloroform. The isolate was then analyzed by thin-layer chromatography (TLC), and the structure was characterized by Fourier Transform Infrared (FTIR) and Nuclear Magnetic Resonance (NMR) spectroscopy. Cytotoxic activity was determined under Presto Blue assay. Based on the result, EPMC from K. galanga showed the cytotoxic effect on B16 cells with an $\mathrm{IC}_{50}$ value of $97.09 \mu \mathrm{g} / \mathrm{mL}$, whereas EPMC showed no significant cytotoxic effect on A549 with an $\mathrm{IC}_{50}$ value of $1407.75 \mu \mathrm{g} / \mathrm{mL}$. It was concluded that EPMC has potential cytotoxic on B16 melanoma cancer cells, but it showed inactive activity against A549 lung cancer cells. Further molecular mechanism underlying EPMC cytotoxic activity needs to be conducted.
\end{abstract}

\section{Introduction}

Cancer is one of the leading causes of death in the world. For several decades, lung cancer has been the most common cancer globally. In 2018, the incidence was $12.3 \%$ of all cancer diagnose [1]. In Indonesia, lung cancer has the highest incidence in men, with 19.4 per 100,000 population with an average death rate of 10.9 per 100,000 population [2]. Similarly, the worldwide incidence of melanoma, a malignant skin cancer deriving from melanocytes, has increased more rapidly than other cancers [3]. The prognosis for patients with malignant melanoma is bleak, with an average survival time of 6-9 months. Melanoma is responsible for $80 \%$ of skin cancer patient mortalities [4].

There are several ways to treat cancer, including surgery, radiation therapy, chemotherapy, and a combination of those treatments. To date, the chemotherapeutic agent is the most common treatment [4]. However, chemotherapy drugs cause side effects such as hair loss, bone marrow suppression, drug resistance, gastrointestinal lesions, neurological dysfunction, and cardiac toxicity [5]. Besides, chemotherapy often causes failure due to the low selectivity of anticancer drugs [6]. Natural compounds represent attractive new drug leads. A recent report revealed that $\sim 50 \%$ of all small molecule therapeutics are based on natural products or their derivatives [7]. Alkaloids such as vincristine, vinblastine, and taxol are examples of anticancer drugs that have long been used, and their molecular mechanisms are known [8]. Thus, exploring natural product isolates for cancer treatment needs to be increased to develop anticancer drugs. 
Kaempferia galanga L., locally called kencur, is a medicinal plant that belongs to the Zingiberaceae family. It is mostly cultivated in south-east Asian countries, for example, China, Malaysia, Thailand, Indonesia, and India [9]. K. galanga rhizomes have been used in traditional medicine to treat several ailments such as fever, amoebiasis, asthma, rheumatism, indigestion, cold and headache, abdominal relief pain and, toothache $[9,10]$. Besides, many studies reported that $K$. galanga has pharmacological activities such as antioxidant [11], antituberculosis [12], analgesic and anti-inflammatory [13, 14], hypopigmentation [15], and anticancer [16]. Pharmacological activities of $K$. galanga rhizomes are mainly due to secondary metabolites of different nature [17]. Ethyl-p-methoxycinnamate (EPMC) is the essential compound reported as a bioactive secondary metabolite of K. galanga rhizome [14].

The potential of EPMC from K. galanga rhizome against anticancer activity needs to be explored further. Several previous studies reported that EPMC has anticancer activity against CL- 6 bile duct cancer cells [18], HepG2 liver cancer cells [19], MCF-7 breast cancer cells [20], and Raji's lymphoma cancer cells [10]. However, the anticancer activity of EPMC on lung and melanoma cancer cells has not been reported yet. This study aimed to isolate EPMC from $K$. galanga rhizomes and investigated its potential for anticancer activity against A549 lung cancer and B16 melanoma cancer cells. A549 cells are adenocarcinomic human alveolar basal epithelial cells in the lungs responsible for the diffusion of substances such as water and electrolytes in the alveoli. These cells are commonly used as model cells to research respiratory diseases such as lung cancer [12]. B16 cells are derived from epithelial mice that produce melanin. Melanin has many living systems functions, and its synthesis alterations occur in many disease states [21]. Although melanin's primary function is to protect skin from UV-induced damage, melanin pigment can also regulate epidermal homeostasis and thus can affect melanoma behavior [22].

\section{Methodology}

The rhizome part of K. galanga was obtained from Sukawening, Garut, West Java. The samples were authenticated in the Biology Department herbarium, Universitas Padjadjaran, Indonesia (Ref. No. 37/HB/02/2021). A549 lung cancer cell and B16 melanoma cancer cell were culture collection of Central Laboratory, Universitas Padjadjaran, solvent DMSO (Sigma-Aldrich Chemical Company, St. Louis, MO, USA); Complete medium of A549 cells consisting of RPMI (Rosewell Park Memorial Institute) 1640 (Gibco, Life Technologies, USA), Penicillin-Streptomycin $1 \%(\mathrm{v} / \mathrm{v})$, FBS (Fetal Bovine Serum) $10 \%$ (v/v) (Gibco, Life Technologies, USA) and fungizone $0.5 \%$ (Sigma-Aldrich Chemical Company, St. Louis, MO, USA); Trypsin-EDTA $0.25 \%$ (SigmaAldrich Chemical Company, St. Louis, MO, USA), PBS (Phosphate Buffer Saline), distilled water, $n$-hexane, ethyl acetate, chloroform.

\subsection{Isolation and Characterization of ethyl-p- methoxycinnamate}

The rhizome of $K$. galanga was washed with water, then dried in an oven at $35^{\circ} \mathrm{C}$. After drying, the sample was ground with a mechanical blender. K. galanga rhizome dry powder (820 g) was then extracted using $2 \mathrm{~L}$ of $n$-hexane solvent by maceration method for $3 \times 24$ hours at $25^{\circ} \mathrm{C}$. The macerated extract was then filtered using a filter funnel and then concentrated using a vacuum rotary evaporator at $45^{\circ} \mathrm{C}$. The concentrated $n$-hexane extract was purified by recrystallization. An impure EPMC crystal was mixed with hot chloroform as a solvent to form a saturated solution to perform recrystallization. The resulting crystals were tested for purity using Thin Layer Chromatography (TLC), Fourier Transform Infra-Red (FTIR) spectroscopy, and Nuclear Magnetic Resonance (NMR).

\subsection{Cell Culture}

These two-cancer cells, A549, and B16 cells were obtained from the Laboratorium Sentral of Universitas Padjadjaran. The cells were grown in RPMI-1640 medium supplemented with $10 \%$ fetal bovine serum (FBS) and $1 \%$ penicillin-streptomycin. Cells were inoculated at a density of $1 \times 10^{5}$ cells in a 6 -well plate and were maintained at $37^{\circ} \mathrm{C}$ in a humidified atmosphere containing $95 \%$ air and $5 \% \mathrm{CO}_{2}$.

\subsection{Cytotoxic Test with Presto Blue Assay Method}

EPMC compound was tested for their cytotoxic activity against A549 and B16 cells using the Presto Blue assay method. A number of $1 \times 10^{4}$ cells were distributed into the 96-well plates and incubated in a $5 \% \mathrm{CO}_{2}$ incubator at $37^{\circ} \mathrm{C}$ for 24 hours. EPMC was dissolved in $10 \%(\mathrm{v} / \mathrm{v})$ of DMSO co-solvent, then it was added to $96-$ well plate with eight concentration series, namely 1000; $500 ; 250 ; 125 ; 63.5 ; 31.25 ; 15.625 ; 7.8125 \mu \mathrm{g} / \mathrm{mL}$ for 24 hours. Cisplatin was used as a positive control. At the end of incubation, the media and extract were discarded and then added with $100 \mu \mathrm{L}$ of PrestoBlue ${ }^{\text {тм }}$ Cell Viability with a ratio of 1: 9. Cells were incubated again for 1-2 hours until a color change was seen in a $5 \% \mathrm{CO}_{2}$ incubator at $37^{\circ} \mathrm{C}$. Living cells will reduce Presto Blue from the blue compound resazurin to the red compound resorufin. Absorption was measured at $570 \mathrm{~nm}$ and $600 \mathrm{~nm}$ (reference wavelength) using a multimode reader [23].

\section{Result and Discussion}

\subsection{Ethyl-p-methoxy cinnamate isolation}

EPMC is found as a major ester and easily isolated compound from the rhizome of K. galanga [24]. Purification of $n$-hexane extracts of the rhizome of $K$. galanga produced a white crystal of EPMC (76.9 g). In case, the percentage of yield was $49.99 \%$. EPMC isolate was then confirmed for purity using Thin Layer Chromatography (TLC). The stationary phase in TLC was in the form of a $\mathrm{GF}_{254}$ silica gel plate, while the mobile phase used was $n$-hexane and ethyl acetate with a ratio of 8:2. 


\subsection{FTIR Characterization}

The Infra-red spectra of the isolated compound showed a very intensely broad peak at $3450 \mathrm{~cm}^{-1}$ for $\mathrm{O}-\mathrm{H}$ bond vibrations, and moderately intense peaks at 1510 and $1600 \mathrm{~cm}^{-1}$ were observed for the aromatic part of $\mathrm{C}=\mathrm{C}$ vibration. The unsaturated $\mathrm{C}-\mathrm{H}$ vibration was observed at $2900 \mathrm{~cm}^{-1}$. This is supported by the presence of absorption at wavenumbers $1367 \mathrm{~cm}^{-1}$ and $1417 \mathrm{~cm}^{-1}$, which indicates the presence of $\mathrm{CH}_{3}$ groups. The $\mathrm{C}-\mathrm{O}$ ether group and $\mathrm{C}-\mathrm{O}$ methoxy group's vibrations were observed at $1200 \mathrm{~cm}^{-1}$ and $1100 \mathrm{~cm}^{-1}$. The para substitution of aromatic was shown at $820 \mathrm{~cm}^{-1}$, which confirms the structure of EPMC.

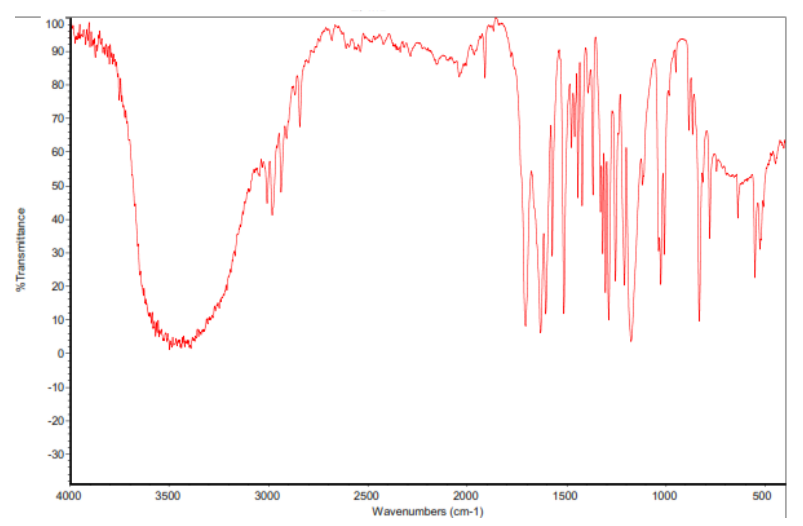

Figure 1. FTIR spectra of EPMC

\subsection{NMR Characterization}

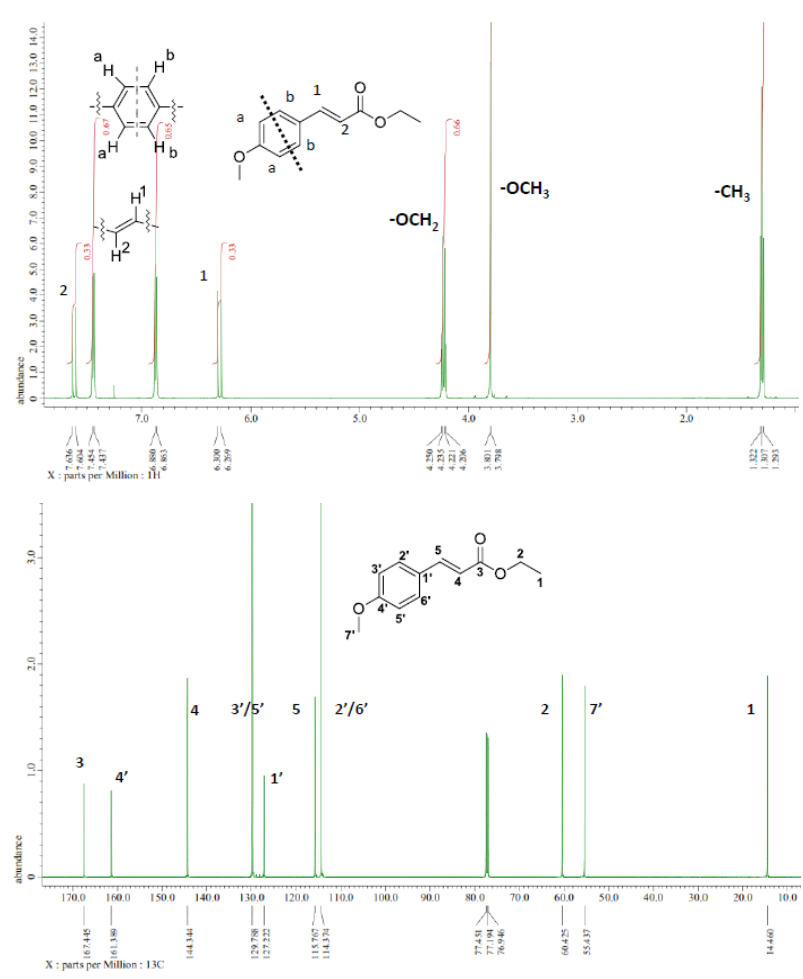

Figure 2. ${ }^{1} \mathrm{H}-\mathrm{NMR}$ spectra (A), and ${ }^{13} \mathrm{C}-\mathrm{NMR}$ spectra of $\operatorname{EPMC}(\mathrm{B})$

Based on the ${ }^{1} \mathrm{H}-\mathrm{NMR}$ spectrum (Figure $2 \mathrm{~A}$ ) of EPMC, two doublet peaks of proton signal indicate a parasubstituted aromatic ring on $\delta 7.454 \mathrm{ppm}$ and $6.880 \mathrm{ppm}$. The appearance of two doublet peaks at $\delta 7.636 \mathrm{ppm}$ and $6.300 \mathrm{ppm}$ shows an alkene proton's signal. Also, other proton signals at $\delta 4.250 \mathrm{ppm}$ and $1.322 \mathrm{ppm}$ indicate an ethoxy group $\left(-\mathrm{OCH}_{2} \mathrm{CH}_{3}\right)$, and at $\delta 3.801 \mathrm{ppm}$, it indicates the methoxy group $\left(-\mathrm{OCH}_{3}\right)$.

The ${ }^{13} \mathrm{C}$-NMR spectrum (Figure $2 \mathrm{~B}$ ) shows seven $\mathrm{C}$ $\mathrm{sp}^{2}$ signals in a range of $\delta \mathrm{C} 167.445-114.375 \mathrm{ppm}$, which are specific signals for $\mathrm{C}=\mathrm{O}$ in ester group $(\delta 167.445$ ppm), oxyaryl ( $\delta 161.389 \mathrm{ppm})$ and $\mathrm{C}=\mathrm{C}$ in an aromatic ring ( $\delta 144.344 \mathrm{ppm}\left(\mathrm{C}-4^{\prime}\right), \delta 129.788 \mathrm{ppm}\left(\mathrm{C}-3^{\prime} / 5^{\prime}\right), \delta$ $127.222 \mathrm{ppm}\left(\mathrm{C}-1^{\prime}\right), \delta 115.767 \mathrm{ppm}(\mathrm{C}-5)$ and $\delta 114.344$

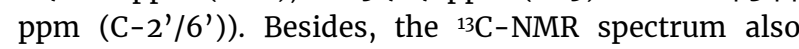
shows three $\mathrm{C}-\mathrm{sp}^{3}$ signals at $\delta 60.425 \mathrm{ppm}\left(-\mathrm{OCH}_{2}\right), \delta$ $55.437 \mathrm{ppm}\left(-\mathrm{OCH}_{3}\right)$, and $\delta 14.460 \mathrm{ppm}\left(-\mathrm{CH}_{3}\right)$.

To ensure the appropriate obtained structure of EPMC, we compared our original spectrum values with other spectra that had been reported. The comparison between original and reference spectrum values can be seen in Table 1 and Table 2.

Table 1. Comparison between isolated and reference EPMC chemical shift of ${ }^{1} \mathrm{H}-\mathrm{NMR}$

\begin{tabular}{|c|c|c|}
\hline Signal of $\mathrm{H}$ & $\begin{array}{c}\delta_{\mathrm{H}} \text { (multiplicity) of } \\
\text { isolated EPMC }\end{array}$ & $\begin{array}{l}\delta_{\mathrm{H}} \text { (multiplicity) of } \\
\text { reference EPMC [14] }\end{array}$ \\
\hline $\mathrm{CH}$ alkene & $\begin{array}{c}7.636(1 \mathrm{H}, \mathrm{d}, 1 \mathrm{xCH} \\
\text { alkene })\end{array}$ & $\begin{array}{c}7.65(1 \mathrm{H}, \mathrm{d}, 1 \mathrm{xCH} \\
\text { alkene })\end{array}$ \\
\hline CH benzylic & $\begin{array}{l}7.454(2 \mathrm{H}, \mathrm{d}, 2 \mathrm{xCH} \\
\text { benzylic })\end{array}$ & $\begin{array}{l}7.42(2 \mathrm{H}, \mathrm{d}, 2 \mathrm{xCH} \\
\text { benzylic })\end{array}$ \\
\hline CH benzylic & $\begin{array}{c}6.880(2 \mathrm{H}, \mathrm{d}, 2 \mathrm{xCH} \\
\text { benzylic })\end{array}$ & $\begin{array}{c}6.90(2 \mathrm{H}, \mathrm{d}, 2 \mathrm{xCH} \\
\text { benzylic })\end{array}$ \\
\hline CH alkene & $\begin{array}{c}6.300(1 \mathrm{H}, \mathrm{d}, 1 \mathrm{xCH} \\
\text { alkene })\end{array}$ & $\begin{array}{c}6.31(1 \mathrm{H}, \mathrm{d}, 1 \mathrm{xCH} \\
\text { alkene) }\end{array}$ \\
\hline$-\mathrm{CH}_{2}$ & $\begin{array}{c}4.250(2 \mathrm{H}, \mathrm{q}, 1 \mathrm{X}- \\
\left.\mathrm{OCH}_{2}\right)\end{array}$ & $\begin{array}{c}4.25(2 \mathrm{H}, \mathrm{q}, 1 \mathrm{x}- \\
\left.\mathrm{OCH}_{2}\right)\end{array}$ \\
\hline$-\mathrm{OCH}_{3}$ & $\begin{array}{c}3.801(3 \mathrm{H}, \mathrm{s}, 1 \mathrm{x}- \\
\left.\mathrm{OCH}_{3}\right)\end{array}$ & $3.82\left(3 \mathrm{H}, \mathrm{s}, 1 \mathrm{x}-\mathrm{OCH}_{3}\right)$ \\
\hline $\mathrm{CH}_{3}$ & $1.322\left(3 \mathrm{H}, \mathrm{t}, 1 \mathrm{xCH}_{3}\right)$ & $1.32\left(3 \mathrm{H}, \mathrm{t}, 1 \mathrm{xCH}_{3}\right)$ \\
\hline
\end{tabular}

Table 2. Comparison between isolated and reference EPMC chemical shift of ${ }^{13} \mathrm{C}-\mathrm{NMR}$

\begin{tabular}{ccc}
\hline Signal of $\mathrm{C}$ & $\begin{array}{c}\delta \mathrm{c} \text { of isolated } \\
\text { EPMC }\end{array}$ & $\begin{array}{c}\delta \mathrm{c} \text { of reference } \\
\text { EPMC [14] }\end{array}$ \\
\hline $\mathrm{C}=\mathrm{O}$ & 167.445 & 167.4 \\
Ar-C & 161.389 & 161.3 \\
$\mathrm{CH}$ alkene & 144.344 & 144.2 \\
Ar-C & 129.788 & 129.7 \\
Ar-C & 127.222 & 127.3 \\
$\mathrm{CH}$ alkene & 115.767 & 115.7 \\
$\mathrm{CH}_{2}$ benzylic & 114.344 & 114.3 \\
$-\mathrm{CH}_{2}$ & 60.425 & 60.2 \\
$-\mathrm{OCH}_{3}$ & 55.437 & 55.3 \\
$-\mathrm{CH}_{3}$ & 14.460 & 14.5 \\
\hline
\end{tabular}

Tables 1 and 2 showed that the NMR data for isolated EPMC had similarities with the NMR reference. It can be seen that the spectrum value of isolated EPMC approached to spectrum value of the reference. In order that we conclude that the structure of isolated EPMC was the same as the reference. 


\subsection{Cytotoxicity Activities of A549 Lung Cancer and B16 Melanoma Cancer Cells}

To examine whether EPMC has anticancer activity, the cytotoxic activity of EPMC against A549 lung cancer and B16 melanoma cancer cells was performed. The analysis was done using the Presto Blue assay method described in the Methodology section. PrestoBlue has been developed for detecting cell-mediated cytotoxicity in vitro. It is a resazurin-based compound converted to the reduced form by mitochondrial enzymes of viable cells in the tested systems. Boncler et al. [25] stated that PrestoBlue assay offers a new alternative to MTT for analyzing cell viability. The assay was fast, simple, and allows continuous monitoring of cultures. Thus, we decided to use the Presto Blue assay method for cytotoxic activity assessment.

Either B16 cell and A549 cell treated with EPMC with various concentration of $1000 ; 500 ; 250 ; 125 ; 63.5 ; 31.25$; $15.625 ; 7.8125 \mu \mathrm{g} / \mathrm{mL}$. Furthermore, the $\mathrm{IC}_{50}$ value was acquired as the EPMC concentration parameter to inhibit $50 \%$ A549 and B16 cell growth. Figures 3A and 4A showed the effect of EPMC on A549 and B16 cell viability for $24 \mathrm{~h}$ treatment. Linear regression of EPMC concentration against corrected absorbance (Fig. 3A) gave a 97.09 $\mu \mathrm{g} / \mathrm{mL}$ value. Treatment of EPMC on B16 cells showed cell growth inhibition in a concentration-dependent manner. Interestingly, we did not observe the decrease of A549 cell growth treated with EPMC with an $\mathrm{IC}_{50}$ value of 1407.75 $\mu \mathrm{g} / \mathrm{mL}$. This $\mathrm{IC}_{50}$ value can be obtained even though the concentration tested was $1000 \mathrm{\mu g} / \mathrm{mL}$ due to poorly linear regression of EPMC concentration toward corrected absorbance of A549 cells (Fig. 4A). Meanwhile, we evaluated cisplatin's cytotoxic activity against A549 cells and B16 cells, given an $\mathrm{IC}_{50}$ value of $18 \mu \mathrm{g} / \mathrm{mL} 53 \mu \mathrm{g} / \mathrm{mL}$, respectively. Prayong et al. [26] stated that cytotoxic activity was categorized into three depending on the $\mathrm{IC}_{50}$ value, which are potential cytotoxic $\left(\mathrm{IC}_{50}<100 \mu \mathrm{g} / \mathrm{mL}\right.$ ), moderate cytotoxic $\left(100 \mu \mathrm{g} / \mathrm{mL}<\mathrm{IC}_{50}<1000 \mu \mathrm{g} / \mathrm{mL}\right)$, and weak cytotoxic activity $\left(\mathrm{IC}_{50}>1000 \mu \mathrm{g} / \mathrm{mL}\right)$. According to that statement, we suggest that EPMC had no cytotoxic activity on A549 cells. Simultaneously, it was cytotoxic on B16 cells, even though the $\mathrm{IC}_{50}$ value of EPMC against B16 cells was still higher than cisplatin. However, EPMC has the potential to be developed as an anticancer agent on B16 cells.

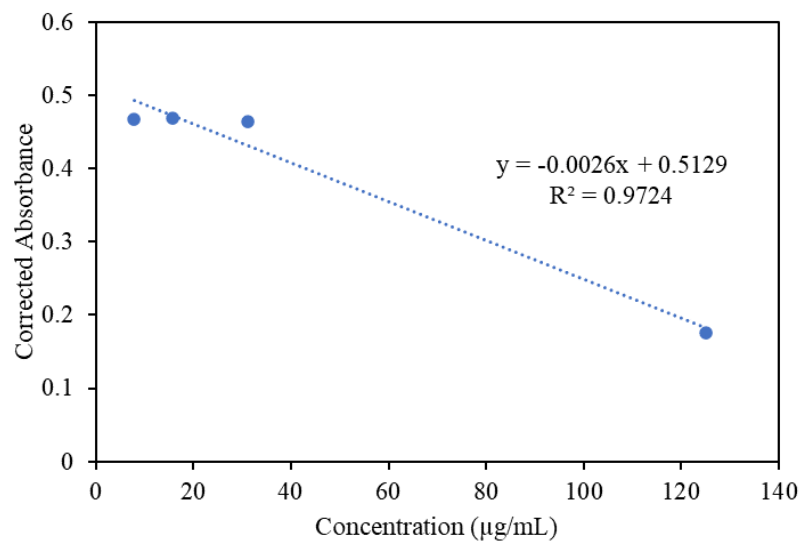

(a)
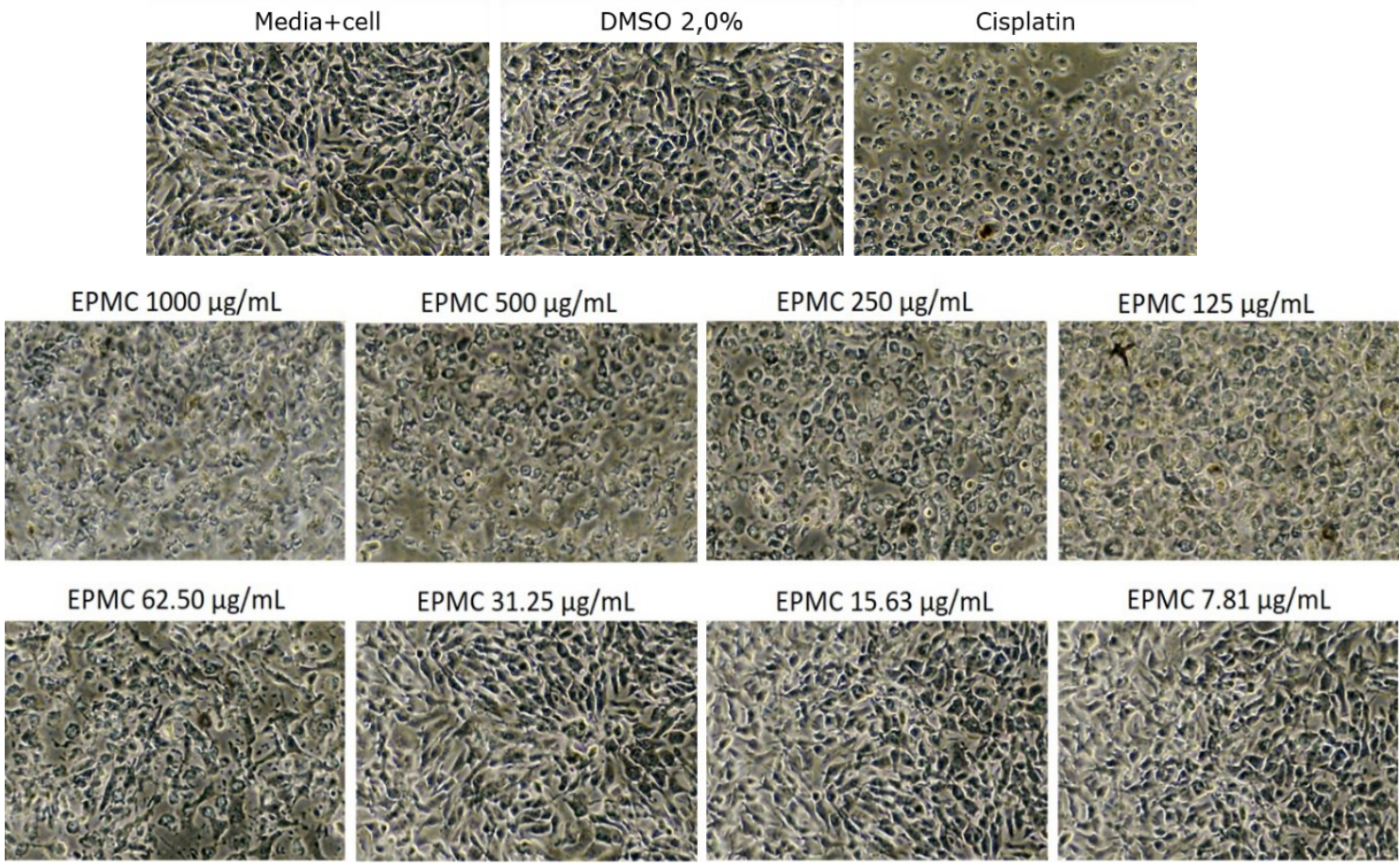

Figure 3. Cytotoxic effects of EPMC on B16 cells. (A) B16 cells were treated using EPMC for $24 \mathrm{~h}$ and determined by Presto Blue assay. (B) Morphological changes of B16 cells were observed using an inverted microscope. 


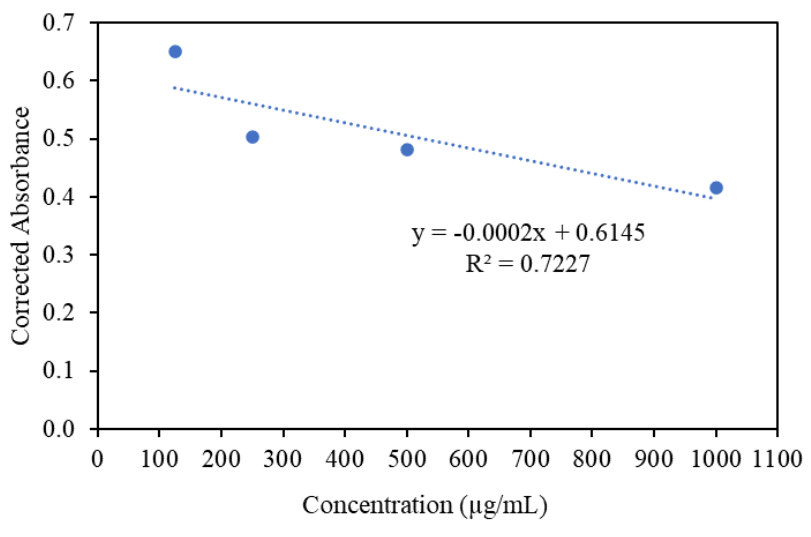

(a)
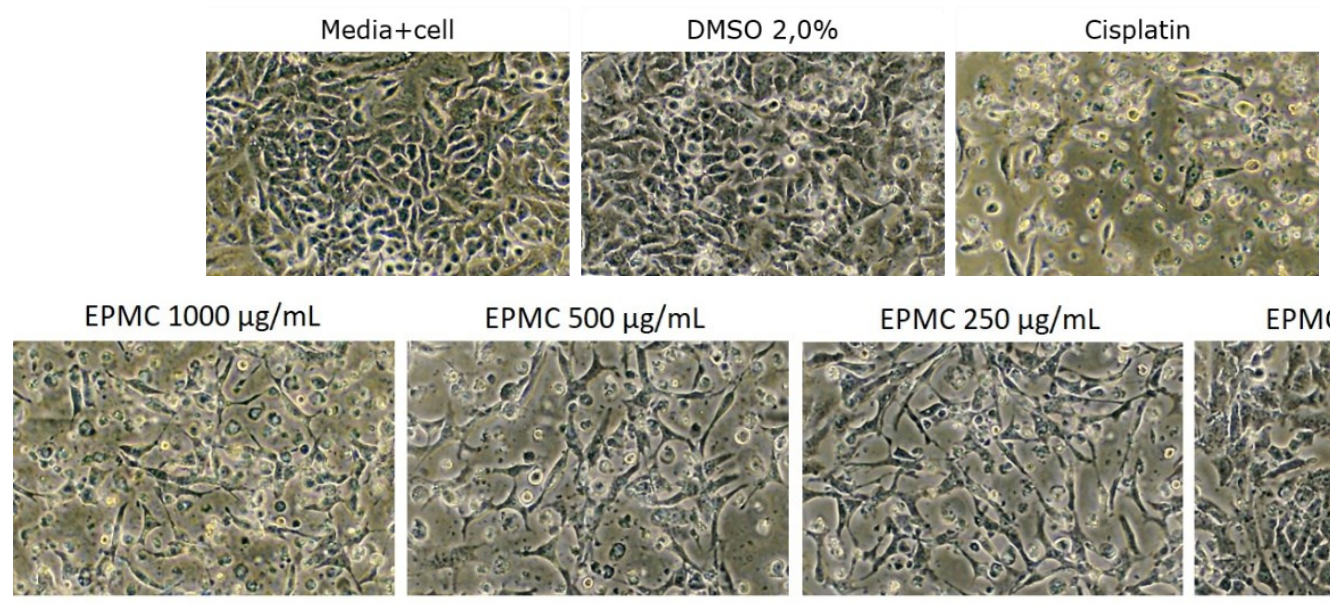

EPMC $125 \mu \mathrm{g} / \mathrm{mL}$

(b)
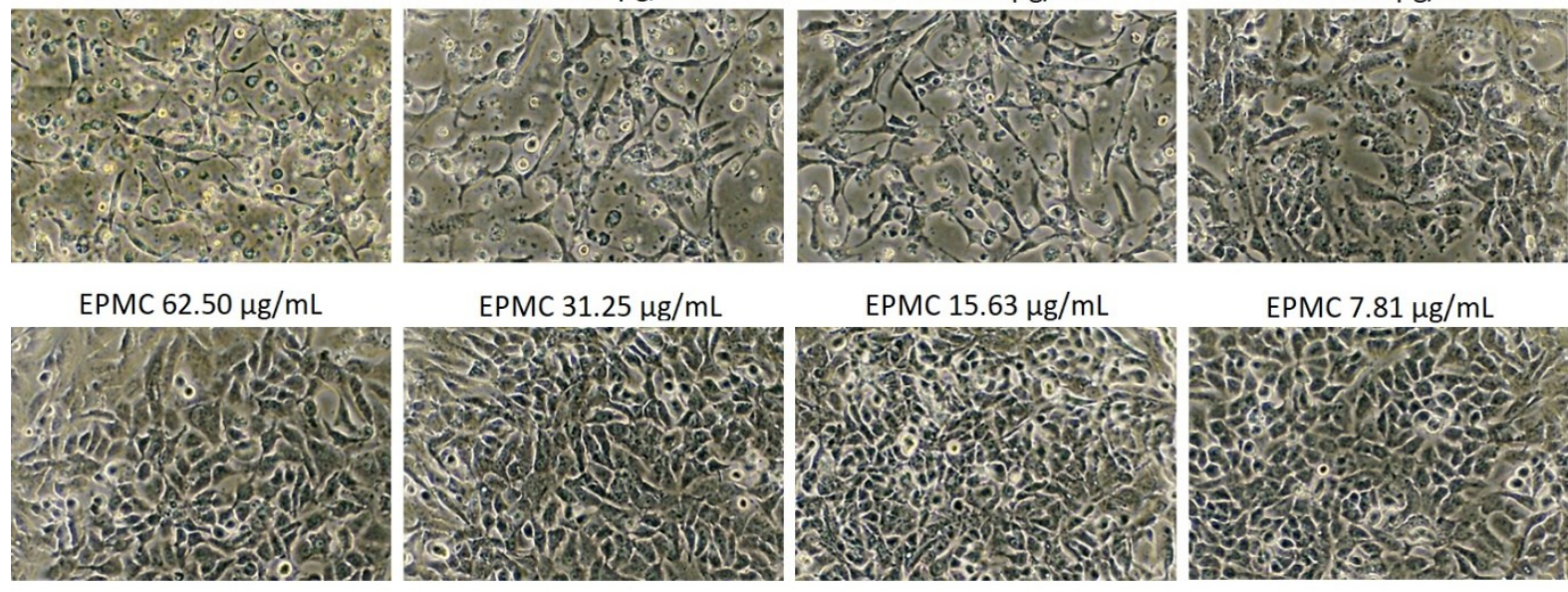

EPMC $7.81 \mu \mathrm{g} / \mathrm{mL}$

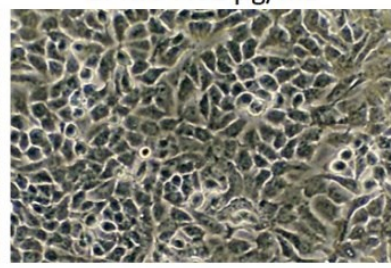

Figure 4. Effects of EPMC on cell viability and morphological changes on A549 cells. (A) A549 cells were treated using EPMC for $24 \mathrm{~h}$. There is no significant decrease in A549 cell growth. (B) Morphological changes of A549 cells were observed using an inverted microscope.

Based on the observation under an inverted microscope, we found that EPMC altered cell morphology on B16 cells. An increase in EPMC concentration caused more cells to undergo morphological alteration. Viable cells exhibited epithelial shape, but after being treated with a specific concentration of samples, the cells exhibited cell shrinkage and rounding (Figure 3B). Supports its noncytotoxic activity, treated cells of A549 did not show any changes in cell morphology (Figure 4B). A549 cells retain their original morphology that showed a long fusiform shape, small size, clear cell boundaries, well-adherent pebble-like growth, placental cytoplasm, and less cytoplasmic granules.

Several studies of EPMC cytotoxic activities on different cancer cells have been reported. Amuamuta et al. [18] reported the $\mathrm{IC}_{50}$ value of EPMC against CL- 6 and OUMS cancer cells were $49.16 \mu \mathrm{g} / \mathrm{mL}$ and $103.18 \mu \mathrm{g} / \mathrm{mL}$. Anticancer activity of EPMC against the HepG2 cell line given $\mathrm{IC}_{50}$ value of $27.1 \mathrm{\mu g} / \mathrm{mL}$ exhibits antiproliferative properties, inducing the significant increase of subGo cell population [19]. In addition, EPMC against PC-3 and
HCT-116 cells showed $\mathrm{IC}_{50}$ value of $39.0 \mu \mathrm{g} / \mathrm{mL}$ and 42.1 $\mu \mathrm{g} / \mathrm{mL}$, respectively [27]. EPMC gave the $\mathrm{IC}_{50}$ value on various types of cancer cells was quite different. We suggest it was caused due to the difference in the genotype and phenotype of these cancer cells.

\section{Conclusion}

In this research, we have isolated ethyl-pmethoxycinnamate from K. galanga, with the percentage of yield was $49.99 \%$. ${ }^{1} \mathrm{H}-\mathrm{NMR}$ and ${ }^{13} \mathrm{C}-\mathrm{NMR}$ analysis confirmed the structure of EPMC, and the spectrum was similar to the reference. The cytotoxic activity of EPMC was evaluated against two cancer cells, B16 cells, and A549 cells. EPMC showed a cytotoxic effect on B16 cells with an $\mathrm{IC}_{50}$ value of $97.09 \mathrm{\mu g} / \mathrm{mL}$. However, EPMC showed no significant cytotoxic activity of A549 lung cancer cells with an $\mathrm{IC}_{50}$ value of $1407.75 \mu \mathrm{g} / \mathrm{mL}$. Considering that EPMC can be an anticancer agent against B16 cells, further research on the cytotoxic mechanism of EPMC against B16 cells and its selectivity on normal cells needs to be investigated. 


\section{Acknowledgment}

This research was funded by Hibah Penelitian Dosen Pemula (044.5/LEMLIT/UNIGA/IV/2020) from Kementerian Riset dan Teknologi/Badan Riset dan Inovasi Nasional (RISTEK-BRIN). Additionally, it was supported by the Research Grant of the Faculty of Mathematics and Natural Science, Universitas Garut (07/BAPPD_UPPM/XI/2019).

\section{References}

[1] Globocan, in, WHO; International Agency for Research on Cancer, 2018,

[2] Haet Nim Lim, Jun-Pil Jang, Hee Jeong Shin, JaeHyuk Jang, Jong Seog Ahn, Hye Jin Jung, Cytotoxic Activities and Molecular Mechanisms of the Beauvericin and Beauvericin G1 Microbial Products against Melanoma Cells, Molecules, 25, 8, (2020), 1974 https://doi.org/10.3390/molecules25081974

[3] Kimberly D. Miller, Leticia Nogueira, Angela B. Mariotto, Julia H. Rowland, K. Robin Yabroff, Catherine M. Alfano, Ahmedin Jemal, Joan L. Kramer, Rebecca L. Siegel, Cancer treatment and survivorship statistics, 2019, CA: A Cancer Journal for Clinicians, 69, 5, (2019), 363-385

https://doi.org/10.3322/caac.21565

[4] Renato G. Martins, Upendra Parvathaneni, Julie E. Bauman, Anand K. Sharma, Luis E. Raez, Michael A. Papagikos, Furhan Yunus, Brenda F. Kurland, Keith D. Eaton, Jay J. Liao, Eduardo. Mendez, Neal Futran, David X. Wang, Xiaoyu Chai, Sarah G. Wallace, Melissa Austin, Rodney Schmidt, D. Neil Hayes, Cisplatin and Radiotherapy With or Without Erlotinib in Locally Advanced Squamous Cell Carcinoma of the Head and Neck: A Randomized Phase II Trial, Journal of Clinical Oncology, 31, 11, (2013), 1415-1421

https://doi.org/10.1200/jco.2012.46.3299

[5] Ahmad Ghorbani, Azar Hosseini, Cancer therapy with phytochemicals: evidence from clinical studies, Avicenna Journal of Phytomedicine, 5, 2, (2015), 8497 https://dx.doi.org/10.22038/ajp.2015.3872

[6] Muhammad Da'i, Ika Trisharyanti D. K., Mekanisme Molekuler Sitotoksisitas Ekstrak Daun Jati Belanda Terhadap Sel Kanker, Universitas Muhammadiyah Surakarta, Surakarta, 2014

[7] Tawona N. Chinembiri, Lissinda H. Du Plessis, Minja Gerber, Josias H. Hamman, Jeanetta Du Plessis, Review of Natural Compounds for Potential Skin Cancer Treatment, Molecules, 19, 8, (2014), 1167911721 https://doi.org/10.3390/molecules190811679

[8] Gordon M. Cragg, David J. Newman, Plants as a source of anti-cancer agents, Journal of Ethnopharmacology, 100, 1, (2005), 72-79 https://doi.org/10.1016/j.jep.2005.05.011

[9] Nupur Srivastava, Ranjana, Shilpi Singh, Amit Chand Gupta, Karuna Shanker, Dnyaneshwar U. Bawankule, Suaib Luqman, Aromatic ginger (Kaempferia galanga L.) extracts with ameliorative and protective potential as a functional food, beyond its flavor and nutritional benefits, Toxicology Reports, 6, (2019), 521-528 https://doi.org/10.1016/j.toxrep.2019.05.014

[10] Hosne Shetu, Kaniz Trisha, Shishir Sikta, Raihanatul Anwar, Sadman Sakib Rashed, Bin Rashed, Pritesh
Dash, Pharmacological importance of Kaempferia galanga (Zingiberaceae): A mini review, International Journal of Pharmacy and Pharmaceutical Sciences, 3, 3, (2018), 32-39

[11] Nuntana Aroonrerk, Narisa Kamkaen, AntiInflammatory Activity of Quercus infectoria, Glycyrrhiza uralensis, Kaempferia galanga and Coptis chinensis, the Main Components of Thai Herbal Remedies for Aphthous Ulcer, Journal Health Research, 23, 1, (2009), 17-22

[12] Divya Lakshmanan, Jim Werngren, Leny Jose, K. P. Suja, Mangalam S. Nair, R. Luxmi Varma, Sathish Mundayoor, Sven Hoffner, R. Ajay Kumar, Ethyl pmethoxycinnamate isolated from a traditional antituberculosis medicinal herb inhibits drug resistant strains of Mycobacterium tuberculosis in vitro, Fitoterapia, 82, 5, (2011), 757-761 https://doi.org/10.1016/j.fitote.2011.03.006

[13] Muhammad Ihtisham Umar, Mohd Zaini Asmawi, Amirin Sadikun, Item J. Atangwho, Mun Fei Yam, Rabia Altaf, Ashfaq Ahmed, Bioactivity-Guided Isolation of Ethyl-p-methoxycinnamate, an Antiinflammatory Constituent, from Kaempferia galanga L. Extracts, Molecules, 17, 7, (2012), 87208734 https://doi.org/10.3390/molecules17078720

[14] Muhammad Ihtisham Umar, Mohd Zaini Asmawi, Amirin Sadikun, Amin Malik Shah Abdul Majid, Fouad Saleih R. Al-Suede, Loiy Elsir Ahmed Hassan, Rabia Altaf, Mohamed B. Khadeer Ahamed, Ethyl-pmethoxycinnamate isolated from kaempferia galanga inhibits inflammation by suppressing interleukin-1, tumor necrosis factor- - \pm , and angiogenesis by blocking endothelial functions, Clinics, 69, 2, (2014), 134-144

http://dx.doi.org/10.6061/clinics/2014(02)10

[15] Hyun-Ju Ko, Hae Jong Kim, Su Yeon Kim, HyeYoung Yun, Kwang Jin Baek, Nyoun Soo Kwon, Whang Wan Kyun, Hye-Ryung Choi, Kyoung-Chan Park, Dong-Seok Kim, Hypopigmentary Effects of Ethyl P-Methoxycinnamate Isolated from Kaempferia galanga, Phytotherapy Research, 28, 2, (2014), 274-279 https://doi.org/10.1002/ptr.4995

[16] Zhi-Heng He, Grace Gar-Lee Yue, Clara Bik-San Lau, Wei Ge, Paul Pui-Hay But, Antiangiogenic Effects and Mechanisms of trans-Ethyl pMethoxycinnamate from Kaempferia galanga L, Journal of Agricultural and Food Chemistry, 60, 45, (2012), 11309-11317 https://doi.org/10.1021/jf304169j

[17] Archana P. Raina, Z. Abraham, Chemical profiling of essential oil of Kaempferia galanga L. germplasm from India, Journal of Essential Oil Research, 28, 1, (2016), 29-34 https://doi.org/10.1080/10412905.2015.1077165

[18] Asmare Amuamuta, Tullayakorn Plengsuriyakarn, Kesara Na-Bangchang, Anticholangiocarcinoma activity and toxicity of the Kaempferia galanga Linn. Rhizome ethanolic extract, BMC Complementary and Alternative Medicine, 17, 1, (2017), 213 https://doi.org/10.1186/s12906-017-1713-4

[19] Benguo Liu, Feng Liu, Chungang Chen, Han Gao, Supercritical carbon dioxide extraction of ethyl pmethoxycinnamate from Kaempferia galanga L. rhizome and its apoptotic induction in human HepG2 cells, Natural Product Research, 24, 20, (2010), 
1927-1932

https://doi.org/10.1080/14786419.2010.490913

[20] Chandra Kirana, Ian R. Record, Graeme H. McIntosh, Graham P. Jones, Screening for Antitumor Activity of 11 Species of Indonesian Zingiberaceae Using Human MCF-7 and HT-29 Cancer Cells, Pharmaceutical Biology, 41, 4, (2003), 271-276 https://doi.org/10.1076/phbi.41.4.271.15673

[21] Enos Tangke Arung, Keisuke Yoshikawa, Kuniyoshi Shimizu, Ryuichiro Kondo, Isoprenoid-substituted flavonoids from wood of Artocarpus heterophyllus on B16 melanoma cells: Cytotoxicity and structural criteria, Fitoterapia, 81, 2, (2010), 120-123 https://doi.org/10.1016/j.fitote.2009.08.001

[22] Radomir M. Slominski, Michal A. Zmijewski, Andrzej T. Slominski, The role of melanin pigment in melanoma, Experimental Dermatology, 24, 4, (2015), 258-259 https://doi.org/10.1111/exd.12618

[23] Ricardo Carneiro Borra, Mônica Andrade Lotufo, Sonia Maria Gagioti, Fabiana de Mesquita Barros, Priscila Maria Andrade, A simple method to measure cell viability in proliferation and cytotoxicity assays, Brazilian Oral Research, 23, 3, (2009), 255-262 https://doi.org/10.1590/S1806$\underline{83242009000300006}$

[24] Ismiarni Komala, Supandi Supandi, Nurhasni Nurhasni, Ofa Suzanti Betha, Eka Putri, Syarifatul Mufidah, Muhammad Fikry Awaludin, Mida Fahmi, Muhammad Reza, Nurkhayati Putri Indriyani, Structure-activity relationship study on the ethyl pmethoxycinnamate as an anti-inflammatory agent, Indonesian Journal of Chemistry, 18, 1, (2018), 60-65 https://doi.org/10.22146/ijc.26162

[25] Magdalena Boncler, Marek Różalski, Urszula Krajewska, Anna Podsędek, Cezary Watala, Comparison of PrestoBlue and MTT assays of cellular viability in the assessment of antiproliferative effects of plant extracts on human endothelial cells, Journal of Pharmacological and Toxicological Methods, 69, 1, (2014), 9-16 https://doi.org/10.1016/j.vascn.2013.09.003

[26] P. Prayong, S. Barusrux, N. Weerapreeyakul, Cytotoxic activity screening of some indigenous Thai plants, Fitoterapia, 79, 7, (2008), 598-601 https://doi.org/10.1016/j.fitote.2008.06.007

[27] Muhammad Ihtisham Umar, Muhammad Adnan Iqbal, Mohamed B. Khadeer Ahamed, Rabia Altaf, Loiy Elsir Ahmed Hassan, Rosenani A. Haque, A. M. S. Abdul Majeed, Mohd Zaini Asmawi, Cytotoxic and Pro-Apoptotic Properties of Ethyl-pMethoxycinnamate and Its Hydrophilic Derivative Potassium-p-Methoxycinnamate, Chemistry Africa, 1, 1, (2018), 87-95 https://doi.org/10.1007/s42250-018-0010-z 